\title{
Pengaruh Pendekatan M-APOS Terhadap Kemampuan Penalaran Matematis Siswa SMP Negeri di Kota Tangerang
}

\author{
Widyah Noviana', Suyono ${ }^{2}$, Lukman El Hakim ${ }^{3}$ \\ ${ }^{1}$ Prodi Pendidikan Matematika FMIPA UNJ Program Magister Pendidikan Matematika \\ Email: widyahnoviana@gmail.com \\ ${ }^{2}$ Dosen Pendidikan Matematika FMIPA UNJ Program Magister Pendidikan Matematika \\ Email: synjkt@yahoo.com \\ ${ }^{3}$ Dosen Pendidikan Matematika FMIPA UNJ Program Magister Pendidikan Matematika \\ Email: lukman561@gmail.com
}

\begin{abstract}
Abstrak
Penelitian ini bertujuan untuk mengetahui pengaruh pendekatan M-APOS terhadap kemampuan penalaran matematis siswa dalam belajar matematika. Penelitian ini dilaksanakan di SMP Negeri 13 Tangerang dan SMP Negeri 4 Tangerang tahun ajaran 2015-2016. Metode penelitian yang digunakan adalah metode quasi experiment. Sampel penelitian diperoleh melalui teknik random sampling sebanyak 100 siswa yang terbagi menjadi 50 siswa kelas eksperimen dan 50 siswa kelas kontrol. Instrumen penelitian telah diuji cobakan kepada 36 siswa kelas VIII di SMP Negeri 13 Tangerang. Setelah melalui proses uji validitas dengan rumus Product Moment didapat 7 soal yang valid dari 7 soal yang ada serta reliabel dengan rumus Alpha Cronbach. Sebelum data di analisis, dilakukan uji prasyarat yaitu uji normalitas menggunakan uji Liliefors dan uji homogenitas menggunakan Levene-Test. Setelah dilakukan perhitungan didapat bahwa data kedua kelompok berdistribusi normal dan homogen. Pengujian hipotesis dengan menggunakan uji-t diperoleh $t_{\text {hitung }}=3,998$ dan $t_{\text {tabel }}=1,6637$. Karena $t_{\text {hitung }}=3,998>t_{\text {tabel }}=1,6637$, maka $H_{0}$ ditolak. Simpulannya adalah terdapat perbedaan kemampuan penalaran matematis siswa dengan menggunakan pendekatan M-APOS dan pembelajaran ekspositori. Hal ini juga menyatakan bahwa kemampuan penalaran matematis siswa yang diberi perlakuan pendekatan M-APOS lebih tinggi dibandingkan kemampuan penalaran matematis siswa yang diberi pendekatan ekspositori.
\end{abstract}

Kata kunci : kemampuan penalaran matematis, pendekatan M-APOS.

\section{PENDAHULUAN}

Pendidikan adalah kunci semua kemajuan dan perkembangan sumber daya manusia yang berkualitas. Melalui pendidikan, manusia dapat mewujudkan semua potensi dirinya, baik sebagai pribadi maupun sebagai warga masyarakat. Dalam rangka mewujudkan potensi diri menjadi kompetensi yang beragam, harus melewati proses pendidikan yang diimplementasikan dalam proses pembelajaran. Hal ini sejalan dengan pendapat Ghozi dalam Sumarmo (2014) bahwa pendidikan adalah usaha masyarakat dan bangsa dalam mempersiapkan generasinya untuk menghadapi tantangan demi keberlangsungan hidup di masa depan. Pendidikan diyakini dapat memaksimalkan potensi siswa sebagai calon SDM yang handal untuk dapat bersikap kritis, logis dan inovatif dalam menghadapi dan menyelesaikan setiap permasalahan yang akan di hadapinya.

Berdasarkan hasil tes Programme for International Students Assessment (PISA ) tahun 2012 Indonesia menempati peringkat 64 dari 65 negara, dengan skor 375 di bawah rata-rata 494. Lebih lanjut menurut Mullis, et.al (2012:42) survey The Trend in International Mathematics and Science Study (TIMSS) yang dikoordinasikan oleh The International Association for The Evaluation of Educational Achivement (IEA) tahun 2011 memaparkan bahwa kemampuan matematis Indonesia pada tingkat 8 berada pada peringkat 38 dari 42 negara, dengan skor 386 di bawah rata-rata 500. Dari fakta di atas menunjukkan bahwa penguasaan dan kemampuan matematis siswa Indonesia masih rendah. Salah satu kemampuan matematis yang dimaksud adalah kemampuan penalaran matematis. Bila dilihat dari persentase hasil pencapaian peserta didik Indonesia dalam TIMSS 2011, kemampuan rata-rata siswa Indonesia pada tiap domain dimensi konten yaitu Bilangan, Aljabar, Geometri dan Pengukuran masih jauh di bawah negara tetangga Malaysia, Thailand dan Singapura. Rata-rata persentase yang paling rendah yang dicapai oleh siswa Indonesia adalah pada 
domain kognitif pada level penalaran (reasoning) yaitu 17\%. Rendahnya kemampuan matematis pada domain penalaran perlu mendapat perhatian khusus.

Berdasarkan uraian di atas terlihat bahwa penalaran sangatlah penting. Dalam Kurikulum KTSP, penalaran merupakan kemampuan dasar matematika yang harus dikuasai siswa sekolah menengah. Menyadari pentingnya penalaran matematis maka diperlukan pendekatan pembelajaran melalui pengkonstruksian mental. Pembelajaan dengan pengkonstruksian mental adalah pembelajaran berdasarkan faham konstruktivisme, dimana pengkonstruksian pemahaman suatu konsep dilakukan oleh individu sendiri dan kelompok. Proses mental yang dimaksud antara lain: mengamati, mencerna, mengerti, menggolonggolongkan, membuat dugaan, menjelaskan, mengukur, dan membuat keismpulan. Salah satu pendekatan pembelajaran melalui pengkonstruksian mental yaitu Pendekatan M-APOS.

Berdasarkan latar belakang masalah, maka penulis mengambil judul "Pengaruh Pendekatan $M$ APOS Terhadap Kemampuan Penalaran Matematis Siswa SMP Negeri di Kota Tangerang." Sehingga yang menjadi hipotesis dalam penelitian ini adalah "Kemampuan penalaran matematis siswa yang diberi perlakuan pendekatan $M$-APOS lebih tinggi dibandingkan dengan siswa yang diberi perlakuan pembelajaran ekspositori." Penelitian ini diharapkan dapat memberi masukan kepada guru mengenai pendekatan M-APOS sebagai alternatif dalam pembelajaran matematika.

\section{KAJIAN TEORI}

\section{Kemampuan Penalaran Matematis}

Penyelesaian soal matematika pada dasarnya memerlukan kemampuan penalaran. Melalui penalaran siswa diharapkan dapat melihat bahwa matematika merupakan kajian yang masuk akal tanpa merasa tergantung pada cara-cara yang instan dalam menyelesaikan persoalan matematika. Siswa dapat berpikir dan bernalar suatu persoalan matematika apabila telah memahami persoalan tersebut. Melalui penalaran siswa merasa yakin bahwa matematika dapat dipahami, dipikirkan, dibuktikan dan dievaluasi.

Menurut Piece (dalam Sugandi, 2014) istilah penalaran sebagai terjemahan dari kata "reasoning", yaitu proses pencapaian kesimpulan logis berdasarkan fakta dan sumber yang relevan. Lebih lanjut Keraf (dalam Martin, 2014) penalaran didefinisikan sebagai proses berpikir dan berusaha menghubung-hubungkan fakta-fakta yang diketahui menuju suatu kesimpulan. Hal ini sejalan dengan pendapat Sariningsih (2014:214) bahwa "penalaran adalah proses atau aktivitas berpikir dalam menarik kesimpulan atau membuat pernyataan baru yang benar berdasarkan pada pernyataan yang telah dibuktikan kebenarannya." Dari pernyataan di atas, penalaran merupakan aktivitas atau proses berpikir dengan cara mengamati kemudian menganalisis masalah setiap informasi yang didapat sehingga dapat menghasilkan suatu bentuk yang masuk akal dan menghasilkan kebenaran dari permasalahan yang belum diketahui.

Secara garis besar penalaran matematis terdiri dari dua jenis yaitu penalaran induktif dan penalaran deduktif. Sumarmo (2007:117) mengemukakan bahwa "penalaran induktif adalah penarikan kesimpulan berdasarkan sejumlah kasus atau data terbatas." Nilai kebenaran dalam penalaran induktif dapat bersifat benar atau salah sedangkan penalaran deduktif adalah penarikan kesimpulan berdasarkan aturan yang disepakati. Nilai kebenaran dalam penalaran deduktif bersifat mutlak benar atau salah dan tidak keduanya bersama-sama. Senada dengan Hosnan (2014:73) penalaran induktif merupakan cara menalar dengan menarik simpulan dari fenomena-fenomena khusus untuk hal-hal yang bersifat umum sedangkan penalaran deduktif adalah cara menalar dengan menarik kesimpulan dari pernyataan-pernyataan atau fenomena yang bersifat umum menuju hal yang bersifat khusus. Lebih lanjut Laird (dalam Sternberg, 2008) mengemukakan bahwa penalaran induktif adalah proses penalaran dari fakta-fakta spesifik untuk mencapai kesimpulan sedangkan penalaran deduktif adalah proses penalaran dari satu atau lebih pernyataan umum terkait dengan apa yang diketahui untuk mencapai satu kesimpulan logis tertentu. Dari pernyataan di atas dapat disimpulkan bahwa penalaran induktif adalah penarikan kesimpulan yang berdasarkan sejumlah masalah dengan data atau informasi terbatas untuk mencapai kesimpulan sedangkan penalaran deduktif adalah penarikan kesimpulan berdasarkan aturan yang disepakati bersama dan bersifat umum menuju hal yang bersifat khusus. Untuk memperjelas pemahaman tentang jenis-jenis penalaran akan disajikan dalam bentuk soal di bawah ini.

\section{Penalaran Induktif}

Soal di bawah ini adalah soal penalaran generalisasi yang merupakan bagian dari penalaran induktif. Arsefa (2014:36) mengungkapkan bahwa penalaran generalisasi adalah penalaran kesimpulan secara umum berdasarkan data terbatas. Berikut adalah contoh soal generalisasi di SMP.

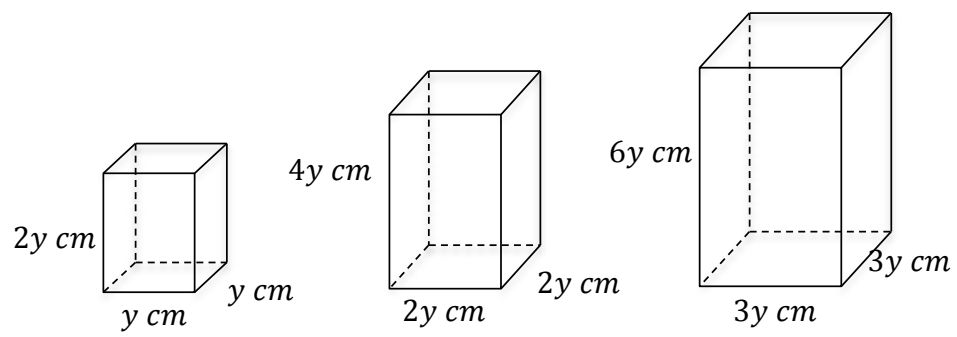




\section{Gambar 1 Contoh Soal Generalisasi SMP}

Balok-balok di atas mempunyai alas berbentuk persegi dan tingginya sama dengan dua kali panjang rusuk alasnya, tentukan luas permukaan balok pada pola ke-n. Soal di atas dapat dikerjakan dengan menganalisis masing-masing panjang rusuk pada balok tersebut.

Penyelesaian:

Panjang rusuk balok pada pola $1: p=y \mathrm{~cm}, l=y \mathrm{~cm}, t=2 y \mathrm{~cm}$

Panjang rusuk balok pada pola $2: p=2 y \mathrm{~cm}, l=2 y \mathrm{~cm}, t=4 y \mathrm{~cm}$

Panjang rusuk balok pada pola $3: p=3 y \mathrm{~cm}, l=3 y \mathrm{~cm}, t=6 y \mathrm{~cm}$

Rumusan luas permukaan balok $=2\{(p \times l)+(p \times t)+(l \times t)\}$

Luas permukaan balok pada pola ke-n

$=2\{(n y \times n y)+(n y \times 2 n y)+(n y \times 2 n y)\}$

$=2\left\{\left(n^{2} y^{2}\right)+\left(2 n^{2} y^{2}\right)+\left(2 n^{2} y^{2}\right)\right\}$

$=2\left(5 n^{2} y^{2}\right)$

$=10 n^{2} y^{2}$

Soal di atas dapat dikembangkan dengan menambahkan pola ke-n dengan luas permukaan $\left(250 n^{2}\right)$ $\mathrm{cm}^{2}$, maka tentukan nilai $y$, kemudian tentukanlah volume balok pada pola ke-10. Jelas terlihat pada soal, penalaran induktif berangkat dari fakta-fakta khusus untuk memperoleh sebuah generalisasi. Setelah siswa mampu membuat generalisasi, maka siswa mampu menggunakan kembali rumus yang telah dibuktikan.

\section{Penalaran Deduktif}

Penalaran deduktif, berangkat dari konsep-konsep matematika yang sudah dibuktikan sebelumnya untuk membuktikan sesuatu yang baru. Di bawah ini adalah contoh penyelesaian penalaran deduktif. Perhatikan bangun ruang $\mathrm{ABCD}$.EFGH, buatlah garis $\mathrm{AC}$ yang menunjukkan panjang diagonal bidang dan tentukan panjang diagonal bidang kubus.

Penyelesaian :
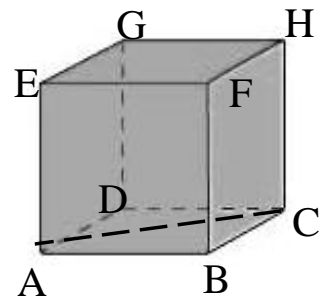

Gambar 2 Diagonal Bidang Pada Kubus

Rusuk kubus $A B C D . E F G H$ adalah $A B, B C, C D, D A, E F, F H, G H, G E, A E, D G, B F$ dan $C H$, karena rusuk kubus sama panjang. Jika dimisalkan panjang rusuk $=\mathrm{p}$, maka:

$A B=B C=C D=D A=E F=F H=G H=G E=A E=D G=B F=C H=p$

Ambil panjang diagonal AC. Untuk mengetahui panjang diagonal AC digunakan rumus pythagoras. Jika $A B=p$, maka $A B=B C$ ( rusuk persegi)

Sehingga, $A C=\sqrt{A B^{2}+B C^{2}} \quad$ (berdasarkan dalil pythagoras)

$$
\begin{aligned}
& A C=\sqrt{p^{2}+p^{2}} \\
& A C=\sqrt{2 p^{2}} \\
& A C=p \sqrt{2}
\end{aligned}
$$

Rumus umum bidang diagonal kubus $=\sqrt{2}$, dengan $\mathrm{p}$ adalah panjang rusuk kubus. Dalam hal ini, siswa dapat mengkonstruk pemahamannya tentang aljabar. Pada contoh di atas, pembuktian dimulai dari konsep matematika yang sudah dibuktikan sebelumnya yaitu penggunakan dalil pythagoras.

Sumarmo (2014:6) "membagi proses penarikan kesimpulan, penalaran induktif berdasarkan karakteristik yang meliputi beberapa kegiatan sebagai berikut": a) penalaran transduktif yaitu penerapan kasus atau sifat khusus yang satu pada kasus khusus yang lainnya, b) analogi yaitu penarikan kesimpulan berdasarkan keserupaan data atau proses, c) generalisasi yaitu penarikan kesimpulan umum berdasarkan sejumlah data yang teramati, d) memperkirakan jawaban, solusi atau kecenderungan, interpolasi dan ekstrapolasi, e) memberikan penjelasan terhadap model, fakta, sifat, hubungan atau pola yang ada, f) menggunakan pola hubungan, menganalisa dan mensintesa beberapa kasus dan menyusun konjektur. Tentang penalaran deduktif. Sumarmo membagi ke dalam beberapa kegiatan diantaranya adalah: a) melaksanakan perhitungan berdasarkan aturan atau rumus tertentu, b) menarik kesimpulan logis berdasarkan inferensi, memeriksa validitas argument, melakukan analisa dan sintesa beberapa kasus, c) menyusun pembuktian langsung, pembuktian tidak langsung dan pembuktian dengan induksi matematika. Berdasrakan pernyataan 
di atas, kemampuan penalaran dapat dikembangkan pada saat siswa memahami suatu konsep, kemudian menemukan dan membuktikan suatu prinsip tertentu. Bila kemampuan bernalar tidak dikembangkan pada siswa, maka bagi siswa matematika hanya akan menjadi materi yang mengikuti serangkaian prosedur dari meniru contoh-contoh tanpa mengetahui maknanya.

\section{Pendekatan $M-A P O S$}

Dasar filosofis dari teori APOS (aksi, proses, objek dan skema) adalah konstrukstivisme sosial tentang bagaimana individu belajar suatu konsep matematika. Proses pembelajaran matematika yang terwujud dari teori konsruktivisme yaitu tantangan masalah, kerja kelompok kecil, dan diskusi kelas. Teori belajar konstruktivis dilakukan dengan memfasilitasi siswa agar memperoleh pengalaman belajar untuk membangun makna terhadap pengetahuan.

Menurut Nurlaelah (dalam Lestari, 2014) bahwa pembelajaran dengan menggunakan teori APOS menekankan pada perolehan pengetahuan melalui aktivitas pendahuluan melalui media komputer, bekerja dalam kelompok (cooperatif learning) dan refleksi. Radford (dalam Brijlall dan Maharaj, 2011) mengemukakan bahwa APOS merupakan pendekatan pembelajaran di komunitas pendidikan matematika di Eropa. Pembelajaran $M$-APOS merupakan pengembangan dari teori APOS yang dikembangkan oleh Dubinsky dan koleganya merupakan hasil elaborasi yang diperkenalkan oleh Piaget dalam menjelaskan perkembangan berpikir logis pada anak-anak. Menurut Arnawa (2009:62) "Dubinsky memperluas ide untuk perkembangan berpikir matematika tingkat tinggi pada mahasiswa". Didalam konsep berpikir matematika tingkat tinggi, teori APOS dikhususkan untuk materi yang memiliki simbol dan bentuk formal di dalam pembelajarannya.

Menurut Lestari (2015:48) bahwa "pembelajaran M-APOS adalah pembelajaran yang berdasarkan teori APOS yang dimodifikasi." Modifikasi yang dimaksud adalah pada fase aksi, dimana kegiatan di laboratorium komputer, diganti menjadi pemberian tugas resitasi yang diberikan sebelum pembelajaran dilaksanakan. Menurut Nurlaelah (2012:174) "pemberian tugas resitasi akan memberikan kesempatan kepada siswa untuk menemukan sendiri semua informasi yang diperlukan. Tugas resitasi ini diberikan sebelum guru memulai pembelajaran. Dari pernyataan di atas, modifikasi yang dimaksud adalah pemberian tugas resitasi yang disajikan berupa lembar kerja tugas (LKT) yang menuntun dan membantu siswa dalam mengkaji pemahaman konsep dalam menyelesaikan persoalan matematika. Pada tahap ini diharapkan siswa sudah memahami konsep yang akan dipelajari selanjutnya sehingga memudahkan siswa untuk mengikuti materi yang akan dipelajari dengan kemampuan matematis.

Menurut Wahyuningtyas (2014:51) langkah-langkah dalam pembelajaran M-APOS terdiri dari "fase aktivitas, fase diskusi kelas dan latihan soal." Hal senada juga diungkapkan Nurlaelah (2012:177) "pelaksanaan pembelajaran $M$-APOS berdasarkan siklus ADL, meliputi tiga fase yaitu fase aktivitas, fase diskusi kelas dan fase latihan soal." Serupa dengan pendapat Maharaj (2010:42) "APOS theory using ACE teaching (activities, class discussion, exercise)". Lebih lanjut Yerizon (2013:557) mengemukakan bahwa " $M$ APOS memiliki empat karakteristik yaitu : 1) pengetahuan matematika dikonstruksi melalui tahapan konstruksi mental aksi, proses, objek dan skema", 2) menggunakan lembaran kerja terstruktur, 3) belajar dalam kelompok kecil, 4 4) menggunakan siklus ADL (aktivitas, diskusi kelas dan latihan). Dari pernyataan di atas, langkah-langkah pembelajaran $M$-APOS terdiri dari aktivitas, diskusi dan latihan soal.

Dubinsky sebagai pengembang teori APOS mendasarkan teorinya pada pandangan bahwa pengetahuan dan pemahaman matematika seseorang merupakan suatu kecenderungan seseorang untuk merespon terhadap suatu situasi matematika dan merefleksikannya pada konteks sosial. Selanjutnya individu tersebut mengkonstruksi atau merekonstruksi ide-ide matematika melalui tindakan, proses, objek matematika yang kemudian diorganisasikan dalam suatu skema. Berikut disajikan diagram dan penjelasan tentang teori APOS.

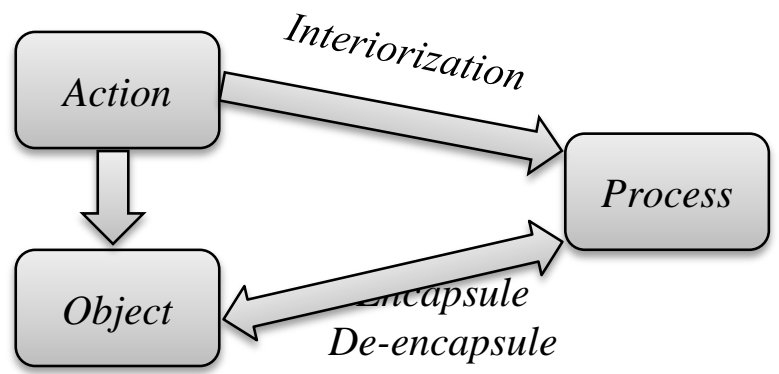

Gambar 3 Diagram Konstruksi Mental APOS

Sumber : Asiala, et al (1990) 
Berdasarkan gambar di atas, memahami konsep matematika dimulai dengan memanipulasi konstruksi mental yang sudah ada dengan memberikan tantangan masalah untuk membentuk aksi, pada tahap aksi dimulai ketika siswa memeroleh LKT, aksi kemudian direnungkan untuk membentuk proses yang kemudian di kristalkan (di encapsulasi) untuk membentuk objek. Objek dapat diurai kembali (di deencapsulasi) menjadi proses. Akhirnya aksi, proses, dan objek dapat di organisasi dalam skema.

Fase aktivitas diawali guru dengan memberikan tugas resitasi atau LKT yang wajib dikerjakan siswa di rumah untuk mengkonstruk pemahaman mereka sebelum materi dijelaskan oleh guru yang merupakan tahap aksi pada teori APOS. Tahap aksi yang selanjutnya adalah merandom siswa untuk mengerjakan hasil tugas resitasi ke depan kelas untuk mengetahui apakah siswa sudah memahami tugas resitasi yang diberikan, pada tahap ini diskusi kelas terjadi untuk memantapkan pemahaman siswa. Fase diskusi dibagi menjadi dua yaitu diskusi kelas dan diskusi kelompok. Pada fase diskusi kelompok, guru memberikan lembar kerja diskusi (LKD). Sebelum diberikan LKD, guru membagi siswa kedalam kelompok dengan kemampuan yang heterogen. Kemudian guru meminta semua siswa berkumpul dengan kelompok yang telah ditentukan oleh guru dan mengerjakan LKD secara berkelompok. Tujuan diberikan LKD selain sebagai aksi siswa di dalam kelas, juga sebagai proses, objek dan skema siswa dalam kerangka pendekatan $M-A P O S$.

Setelah siswa selesai mengerjakan LKD bersama dengan kelompoknya. Dengan dipimpin guru, beberapa siswa dipilih guru sebagai perwakilan dari beberapa kelompok untuk maju ke depan kelas mempresentasikan hasil diskusi mereka. Guru juga meminta kelompok lain untuk memberikan tanggapan. Diakhir diskusi, guru mengulas kembali penjelasan siswa. Fase latihan soal diberikan di akhir pembelajaran untuk mengetahui tingkat kemampuan matematis siswa dan jenis kesalahan yang dilakukan siswa. Tujuan diberikannya latihan soal untuk mengkonstruk skema dalam kerangka pendekatan $M-A P O S$. Siswa dikatakan telah memiliki skema yang baik, apabila telah mampu mengkristalkan pemahamannya dan mampu menguraikannya kembali sesuai dengan kemampuan matematis yang dimilikinya.

Penelitian yang relevan di dalam penelitian ini yaitu Nurlaelah (2009), Yerizon (2013) dan Wahyuningtyas (2014). Pada penelitian yang relevan menyimpulkan bahwa pembelajaran matematika menggunakan pendekatan $M-A P O S$ dapat meningkatkan daya matematika siswa, meningkatkan kemandirian belajar siswa dan mengatasi kesalahan siswa dalam menyelesaikan soal cerita materi kubus dan balok. Hal ini menjadi potensi bagi peneliti untuk dikaji lebih lanjut dan akan menjadi wawasan pengetahuan baru. Perbedaan antara penelitian terdahulu dengan penelitian ini adalah ranah kognitif, yaitu kemampuan penalaran matematis di tingkat SMP.

\section{METODE PENELITIAN}

Penelitian ini merupakan penelitian kuantitatif dan termasuk penelitian eksperimen semu (quasi experiment) karena peneliti tidak mungkin melakukan kontrol atau manipulasi pada semua variabel yang relevan, kecuali beberapa variabel yang diteliti. Desain eksperimen dalam penelitian ini dapat digambarkan sebagai berikut:

$\begin{array}{lccc}\text { Kelas } & & \text { Treatment } & \text { Test } \\ \text { Kelas Eksperimen } & : \mathrm{R} & X_{1} & \mathrm{O} \\ \text { Kelas Kontrol } & : \mathrm{R} & - & \mathrm{O}\end{array}$

Keterangan:

$\mathrm{R} \quad$ : Random

O : Tes Kemampuan Penalaran Matematis

$X_{1} \quad$ : Perlakuan Pendekatan $M-A P O S$

: Perlakuan Pembelajaran Ekspositori

Populasi dalam penelitian ini adalah populasi target seluruh siswa SMP Negeri di Tangerang tahun ajaran 2015-2016 dan populasi terjangkaunya adalah seluruh siswa SMP Negeri 13 Tangerang dan SMP Negeri 4 Tangerang tahun ajaran 2015-2016. Sampel penelitian diperoleh melalui teknik random sampling sebanyak 100 siswa yang terbagi menjadi 50 siswa kelas eksperimen dan 50 siswa kelas kontrol. Instrumen yang digunakan dalam penelitian ini yaitu instrument tes kemampuan penalaran matematis berupa tes tertulis. Teknik analisis data menggunakan uji- $t$ dengan bantuan SPSS 22.

\section{EKSPERIMEN DAN PEMBAHASAN}

Hasil analisis kemampuan penalaran matematis siswa pada kelompok yang diberi pendekatan $M$ APOS dan kelompok pembelajaran ekspositori secara deskriptif disajikan pada Tabel 1. 
Tabel 1 Statistik Deskriptif Data Kemampuan Penalaran Matematis

\begin{tabular}{|l|l|l|}
\hline \multirow{2}{*}{ Statistik } & \multicolumn{2}{|c|}{ Pembelajaran } \\
\cline { 2 - 3 } & Pendekatan M-APOS & Pembelajaran Ekspositori \\
\hline $\mathrm{N}$ & 50 & 50 \\
\hline Min & 4 & 1 \\
\hline Max & 27 & 24 \\
\hline Rata-rata & 16,14 & 11,46 \\
\hline Varians & 36,45 & 32,05 \\
\hline Standar Deviasi & 6,04 & 5,66 \\
\hline
\end{tabular}

Berdasarkan Tabel 1 hasil tes kemampuan penalaran matematis siswa yang diberi perlakuan pendekatan $M$-APOS dengan jumlah sampel 50 siswa memperoleh skor minimal sebesar 4, skor maksimal sebesar 27, rata-rata skor sebesar 16,14, varians sebesar 36,45 serta standar deviasi sebesar 6,04 sedangkan hasil tes kemampuan penalaran matematis siswa yang diberi perlakuan pembelajaran ekspositori dengan jumlah sampel 50 siswa memperoleh skor minimal sebesar 1, skor maksimal sebesar 24, rata-rata skor sebesar 11,46, varians sebesar 32,05 serta standar deviasi sebesar 5,66.

Selanjutnya dilakukan uji prasyarat analisis data, berdasarkan uji normalitas untuk kelas yang diberi pendekatan $M$-APOS diperoleh 0,210>0,05 dan uji normalitas untuk kelas yang diberi pembelajaran ekspositori adalah 0,513 >0,05. Hal ini berarti bahwa kemampuan penalaran matematis pada siswa yang diberi perlakuan pendekatan $M-A P O S$ dan ekspositori berdistribusi normal. Sedangkan uji homogenitas pada kelas yang diberi pendekatan $M-A P O S$ dan pembelajaran ekspositori adalah 0,608 $>0,05$. Hal ini berarti bahwa kemampuan penalaran matematis siswa yang diberi perlakuan pendekatan $M-A P O S$ dan ekspositori memiliki varians yang sama. Kesimpulannya adalah kelas yang diberi pendekatan $M-A P O S$ dan pembelajaran ekspositori berdistribusi normal dan homogen.

Setelah uji prasyarat terpenuhi, maka dapat dilakukan pengujian hipotesis dengan menggunakan uji$t$. Hasil perhitungan dengan uji- $t$ mengenai kemampuan penalaran matematis dilakukan menggunakan SPSS 22, disajikan dengan Tabel 2 sebagai berikut:

Tabel 2 Independent Samples Test

\begin{tabular}{|ll|l|l|l|l|l|}
\hline \multirow{2}{*}{$\begin{array}{l}\text { Levene's } \\
\text { Test for } \\
\text { Equality of } \\
\text { Variances }\end{array}$} & \multicolumn{2}{l|}{ t-test for Equality of Means } \\
\cline { 2 - 6 } & F & Sig. & T & df & Sig. (2-tailed) \\
\hline $\begin{array}{l}\text { Equal variances } \\
\text { assumed } \\
\begin{array}{l}\text { Equal variances } \\
\text { not assumed }\end{array}\end{array}$ & 5 & .608 & 3.998 & 98 & .000 \\
\hline
\end{tabular}

Berdasarkan hasil perhitungan uji-t terlihat bahwa siswa yang diberi perlakuan pendekatan $M-A P O S$ dan pembelajaran ekspositori diperoleh $t_{\text {hitung }}=3,998$, pada taraf signifikansi $\alpha=0,05$ dengan dk=98 bila dicocokkan dengan nilai $t_{\text {tabel }}=1,6637$.

Karena $t_{\text {hitung }}=3,998>t_{\text {tabel }}=1,6637$, maka $H_{0}$ ditolak. Simpulannya adalah terdapat perbedaan kemampuan penalaran matematis siswa dengan menggunakan pendekatan $M-A P O S$ dan pembelajaran ekspositori. Hal ini juga menyatakan bahwa kemampuan penalaran matematis siswa yang diberi perlakuan pendekatan $M-A P O S$ lebih tinggi dibandingkan kemampuan penalaran matematis siswa yang diberi pendekatan ekspositori.

Berdasarkan hasil tersebut memberikan gambaran bahwa pembelajaran melalui pendekatan $M$ APOS lebih memberikan akses kepada siswa untuk mengkonstruk kemampuan matematisnya. Pembelajaran dengan pendekatan $M$-APOS difasilitasi dengan pemberian Lembar Kerja Tugas (LKT) sebagai aktivitas pertama siswa yang dikerjakan dirumah. Aktivitas kedua yaitu diskusi kelas yang berguna untuk memantapkan pemahaman siswa terhadap LKT yang telah mereka kerjakan, aktivitas ketiga yaitu diskusi kelompok dengan pemberian Lembar Kerja Diskusi (LKD) serta latihan yang berguna untuk mengkonstruk kemampuan matematis siswa secara individu. Kegiatan yang dilakukan berulang-ulang mampu mengkonstruk kemampuan matematis siswa menjadi lebih baik. Pada kelompok yang diberi perlakuan pembelajaran ekspositori, siswa dijadikan objek dan guru sebagai sumber belajar dan penyaji. Hal ini 
mengakibatkan siswa bersifat pasif karena siswa hanya menerima apa yang disampaikan oleh guru sehingga siswa tidak bisa mengetahui kemampuan dan keterampilan yang dimilikinya.

\section{KESIMPULAN}

Kesimpulan penelitian ini adalah kemampuan penalaran matematis siswa yang diberi pendekatan $M$ APOS lebih tinggi dibandingkan dengan siswa yang diberi perlakuan pembelajaran ekspositori. Hal ini menunjukkan bahwa rancangan pembelajaran M-APOS (Modifikasi Aksi Proses Objek Skema) dapat digunakan guru sebagai alternatif dalam pembelajaran matematika yang memerlukan kemampuan matematika tingkat tinggi.

\section{DAFTAR PUSTAKA}

Arnawa, I. (2009). "Mengembangkan Kemampuan Mahasiswa dalam Memvalidasi Bukti pada Aljabar Abstrak Melalui Pembelajaran Berdasarkan Teori APOS.” Disertasi. Bandung: UPI.

Arsefa, Dezi. (2014). Kemampuan Penalaran Matematika Siswa Dalam Pembelajaran Penemuan Terbimbing. Diselenggarakan oleh Program Pasca Sarjana Pendidikan Matematika, STKIP Siliwangi Bandung, 15 Januari 2014 (hal 270-277). Diakses dari Diakses dari https://www.google.com/search?q=publikasi.stki psiliwangi..ac.id\% 2Ffiles\%2F2014\% 2F...\%2FProsiding-15-Januari 2 014. pd...\&ie=utf-8\&oe=utf-8.

Bernard. M. (2014). Pengaruh Pembelajaran Dengan Menggunakan Multimedia Macromedia Flash Terhadap Kemampuan Penalaran Matematik. Diselenggarakan oleh Program Pasca Sarjana Pendidikan Matematika, STKIP Siliwangi Bandung, 15 Januari 2014 (hal. 424-429). Diakses dari https://www.google.com/search?q=publikasi.stki psiliwangi..ac.id\% 2Ffiles\%2F2014\%2F...\%2FProsiding-15Januari 2 014. pd...\&ie=utf-8\&oe=utf-8.

Hosnan, M. (2014). Pendekatan Saintifik dan Kontekstual Dalam Pembelajaran Abad 21. Bogor: Ghalia Indonesia.

Lestari, Karunia E. (2014). Penerapan Model Pembelajaran M-APOS untuk Meningkatkan Kemampuan Pemecahan Masalah Matematis Siswa SMP. Jurnal Pendidikan Unsika, ４5-52. ISSN 2338-2996.

Maharaj \& Brijlall. (2014). A Framework for the Development of Mathematical Thinking With Teacher Trainees: The Case of Continuity of Functions. Diakses dari http://files.eric.ed.gov /fulltext/ED52 7675.pdf.

Mullis,et al. (2011). TIMSS 2011 International Result in Mathematics. Diakses dari. timssandpirls.bc.edu/timss2011/...T11_IR_Mathema tics_Full Book.pdf.

Nurlaelah, E. (2009). "Pencapaian Daya dan Kreativitas Matematik Mahasiswa Calon Guru Melalui Pembelajaran Berdasarkan Teori APOS.” Disertasi. Bandung: UPI.

Nurlaelah, E. (2012). Model Pemberian Tugas Resitasi (M-APOS) yang Dilaksanakan Dengan Bahasa Inggris Dalam Mengembangkan Kemampuan Komunikasi Matematis dan Kepercayaan Diri Mahasiswa Calon Guru. Jurnal Pengajaran MIPA, 173-182. Volume 17.

Pisa. (2012). PISA In Focus. Diakses dari http://www.oecd. org/pisa/keyfindings /pisa-2012-results-overview.pdf.

Sariningsih, R. (2014). Peningkatan Kemampuan Penalaran Matematik Siswa SMA Menggunakan Pembelajaran Kontekstual. Diselenggarakan oleh Program Pasca Sarjana Pendidikan Matematika, STKIP Siliwangi Bandung, 15 Januari (hal 2014 213-218). Diakses dari https ://www.google.com/search?q=publikasi.stkipsiliwangi.ac.id\%2Ffiles $\% 2 F 2014 \% 2 F . . . \% 2 F P r o s i d i n g-15-J a n u a r i-$ 2014.pd...\&ie $=$ utf-8\&oe $=$ utf- 8

Sternberg, Robert J. 2008. Psikologi Kognitif. Yogyakarta: Pustaka Pelajar

Sumarmo, U. (2014). Pengembangan Hard Skill dan Soft Skill Matematik Bagi Guru dan Siswa untuk Mendukung Implementasi Kurikulum 2013. Diselenggarakan oleh Program Pasca Sarjana Pendidikan Matematika, STKIP Siliwangi Bandung, 15 Januari 2014(hal. 4-15). Diakses dari https://www.google.com/search?q=publikasi.stkipsiliwa ngi.ac.id\%2Ffiles \%2F2014\%2F...\%2FProsiding-15Januari2014.p...\& ie=utf-8\&oe $=$ utf-8.

Sugandi, Asep I. (2014). Pendekatan Kontekstual Sebagai Pendekatan Dalam Pembelajaran yang Humanis untuk Meningkatkan Kemampuan Berpikir Matematis Tingkat Tinggi. Diselenggarakan oleh Program Pasca Sarjana Pendidikan Matematika, STKIP Siliwangi Bandung, 15 Januari 2014 (hal. 24-38). Diakses dari https:// 
www.google.com/search? q=publikasi.stkipsiliwangi.ac.id\%2Ffiles\% 2 F2014\%2FF...\%2FProsiding-15-Januari2014. pd...\&ie $=$ utf $-8 \& o e=u t f-8$

Wahyuningtyas, dkk. (2014). Penerapan Pembelajaran M-APOS dengan Siklus ADL dalam Mengatasi Kesalahan Siswa Menyelesaikan Soal Cerita Pada Materi Volume Kubus dan Balok di Kelas VIII E SMPN 7 Jember Semester Genap Tahun Ajaran 2012/2013. Kadikma, Vol. 5 No.2, 47-54.

Yerizon. (2013). Peningkatan Kemandirian Belajar Mahasiswa Melalui Pengunaan Pendekatan Modifikasi APOS. Diselenggarakan oleh FMIPA, Universitas Lampung 2013 (hal 557-563). Diakses dari. http://jurnal.fmipa.unila.ac.id/index.php/semirata/article/view/933/752. 